\title{
Agama dan Kepemimpinan Nasional
}

\author{
Paul Suparno
}

\begin{abstract}
All of Indonesian leaders are the faith people, and the former president Stewart is a worship person. On the contrary, they can not solve the problems of this nation, and one of them has decided and conducted the policies that supporting the process of destruction of indonesian progress so that those policies caused long crisis up to now. Indonesian faces the problem of corruption, social cinflict, human rights, law enforcement etc. According to author of this article, it is clear that Indonesia is democracy state, for that reason, the leader that expected is the leader who has higfh morality and a brave to against corruption, to build Indonesian unity, to appreciate human rights etc.
\end{abstract}

$S^{e}$ emua pimpinan nasional kita selama ini adalah orang beragama, bahkan mantan presiden Soeharto sangat nampak beribadah. Tetapi ternyata mereka tidak dapat memecahkan persoalan bangsa ini, bahkan diantara mereka telah membuat keputusan dan tindakan yang ikut menghancurkan kemajuan bangsa ini sehingga terjadi krisis yang begitu panjang sampai hari ini. Para pimpinan lembaga negara, para wakil rakyat dalam DPR dan DPRD, dan tokoh-tokoh bangsa yang korupsi, termasuk yang dianggap koruptor besar, juga beragama. Mereka jelas terlibat dalam penghancuran bangsa ini. Para caleg atau capres yang dalam kampanyenya menggunakan money politics pun beragama.

Mengamati pengalaman tersebut, orang dapat bertanya secara kritis apakah agama dapat punya peran positif dalam kepemimpinan bangsa ini sesudah pemilu 2004. Apakah agama tidak disalahgunakan oleh pimpinan justru untuk kepentingan mereka sendiri? Apakah sungguh dibutuhkan pimpinan yang beragama untuk mengentaskan persoalan bangsa Indonesia, atau justru tidak perlu karena dalam. perjalanan panjang bangsa ini pimpinan yang beragama tidak mampu menangani persoalan bangsa. Ada pendapat yang mengungkapkan para pimpinan itu tidak mampu karena mereka tidak sungguhsungguh beragama. Pendapat inj menyimpulkan bila para pimpinan itu agamawan, pasti hasilnya lain. Apakah benar seorang agamawan dapat sekaligus menjadi pimpinan negara dan dijamin efektif?

\section{Persoalan Besar Bangsa}

Bangsa Indonesia sedang mengalami persoalan besar yang menjadikan krisis tidak kunjung selesai. Persoalan besar itu antara lain korupsi, konflik masyarakat, ketidakadilan, rendahnya penegakan hukum, hak asasi dan penghargaan terhadap nilai kemanusiaan masih rendah, akhlak para pemimpin yang tidak terpuji. 
Korupsi serta merajalela di semua level kehidupan bahkan sampai ke dunia pendidikan maupun departemen agama, yang sebenarnya diharapkan menjadi bidang yang menentang korupsi. Hampir tidak ada bidang kehidupan yang lepas dari praktek korupsi. Usaha perang melawan korupsi tidak kunjung ada hasil dan bila ada hasil pun hanya mereka yang korupsi kecil. Gerakan masyarakat anti korupsi tidak mudah berkembang karena memang banyak orang terlibat korupsi. Keadaan semakin runyam karena banyak pejabat yang ikut dalam jaringan korupsi ini. Jelas korupsi sudah sangat menjerat bangsa Indonesia sehingga sulit untuk lepas dari krisis ekonomi, sosial, dan moral yang begitu lama. Bahkan di tengah masyarakat sudah ada nada pesimis bahwa budaya korupsi tidak dapat diatasi. Akhirnya banyak orang berpikir, yang penting selamat sendiri, tanpa memperhatikan nasib bangsa secara keseluruhan.

Konflik antar warga masyarakat cukup lama telah menggerogoti persaudaraan, persatuan, dan rasa kebangsaan di tengah bangsa Indonesia. Konflik warga masyarakat yang ditimbulkan karena perbedaan suku, keadaan sosial, agama, kepentingan politik telah memakan jiwa sangat banyak. Ribuan sesama warga dalam 8 tahun terakhir telah dikorbankan tanpa ada ujung pangkalnya. Kita sampai heran, mengapa sesama warga negara Indonesia saling bunuh dan tidak mudah menyelesaikan konflik lewat pembicaraan, lewat perundingan. Dari konflik-konflik tersebut yang menyebabkan korban jiwa besar adalah konflik karena agama, suku. dan politik. Beberapa konflik politik menyebabkan sekelompok orang lebih suka memisahkan diri dari negara kesatuan. Semua itu jelas menjadi persoalan bagi bangsa ini bila ingin tetap bersatu. Konflik kadang dipertajam karena beberapa pimpinan yang seharusnya bersikap lebih netral dan membela persaudaraan, malah memanaskan suasana dengan keberpihakkan pada kelompok tertentu. Persoalan konflik yang makan banyak nyawa, jelas menunjukkan bahwa penghargaan bangsa ini terhadap nilai kehidupan manusia, belumlah sangat tinggi. Hak asasi manusia belum secara signifikan ditegakkan. Kadang terlihat bahwa manusia dihargai lebih rendah dari benda mati atau binatang.

Ketidakadilan, terlebih ketidakadilan sosial, juga merupakan persoalan besar bangsa ini. Perlakuan yang adil bagi seluruh warga belum sepenuhnya terlaksana, masih ada diskriminasi perlakuan di depan hukum. Tidak adanya pembelaan bagi kasus-kasus yang menyangkut orang kecil dalam berperkara dengan lembaga besar atau pemerintah,misal,peristiwa penggusuran warga miskin dengan menghancurkan semua "gubuk" mereka. Hal inj menunjukkan bahwa bangsa ini belum memperhatikan nasib masyarakat kecil dan miskin. Padahal salah satu ukuran kemakmuran dan keadilan sosial suatu negara adalah bagaimana negara tersebut membantu dan memperhatikan kelompok masyarakat yang kecil dan miskin. Banyak calon pemimpin lembaga negara, caleg, capres, bahkan calon kepala desa bila sedang kampanye untuk dipilih, suka bicara soal perhatian dan pengentasan masyarakat miskin, tetapi setelah menjadi pejabat lupa konstituennya. Inilah salah satu yang membuat masyarakat lapisan bawah (petani) dalam pemilu 2004 ini apatis dan mengungkapkan, "aku memilih siapapun, akan tetap jadi petani miskin, dan membeli apa-apa ya tetap mahal."

Bangsa ini sulit maju juga disebabkan karena rendahnya penegakan hukum yang ada. Banyak pelanggaran hukum terjadi dan 
tidak terselesaikan dengan baik. Penegakan hukum menjadi persoalan berat dan sulit, karena justru para pimpinan yang seharusnya memberikan contoh menegakkan hukum malah melanggar hukum atau mencari keringanan atas perlakuan hukum. Kadang terjadi orang yang salah dibebaskan, sedangkan yang tidak bersalah malah masuk penjara karena tidak mempunyai pembela yang dapat membantu. Maka di masyarakat ada suara, bila ada uang segalanya dapat diselesaikan. Itu berarti bahwa bagi orang kaya, kesalahan dan pelanggaran hukum apapun dapat dicarikan jalan untuk bebas,sedangkan bagi penduduk miskin, barangkali hanya mencuri ayam kampung, harus masuk penjara beberapa minggu. Yang lebih menyedihkan, para penegak hukum sendiri sering mempermainkan hukum.

Bangsa ini tidak mempunyai banyak pimpinan yang dapat dicontoh dalam hal hidup bermoral dan berakhlak. Banyak pimpinan yang hidup morainya tidak beres, yang akhlaknya bejat seperti korupsi, tidak jujur, hanya mencari keuntungan untuk diri dan kelompoknya sendiri, main kuasa, menyalahgunakan kekuasaan, moral seksnya rendah, tidak rela berkorban bagi kepentingan bangsa, suka memboroskan uang negara, dll. Makin mengerikan lagi, bahwa yang berakhlak rendah itu secara formalitas "beragama" dan dilihat banyak orang "beribadah." Mereka "berdoa" tetapi hidup moralnya tidak berubah menjadi baik. Mereka pergi ke tempat ibadat dan bahkan duduk di depan, tetapi hidupnya tidak bermoral. Bila bangsa ini dipimpin oleh orang-orang munafik seperti itu, maka bangsa ini memang tidak akan maju dan tidak akan mengatasi persoalannya.

Beberapa persoalan besar itulah yang menjadi tatapan pimpinan nasional dan para pimpinan lain sesudah pemilu 2004 . Setelah mereka selesai dengan "keramaian kampanye dan pemilu", mereka harus berpikir bagaimana dapat menghadapi tantangan berat bangsa ini. Apa yang diharapkan dari pimpinan nasional pasca pemilu di saat krisis bangsa seperti ini? Karakter dan kemampuan macam apa yang diharapkan dari pimpinan nasional untúk menghadapi persoalan tersebut? Apakah mereka akan mampu ikut mengentaskan bangsa ini lebih maju?

\section{Karakter Pimpinan Nasional yang Dibutuhkan}

Secara umum, bila bangsa ini ingin keluar dari krisis diatas, dibutuhkan pimpinan nasional yang mempunyai karakter, kemampuan, dan keberanian untuk menghadapi tantangan diatas. Beberapa karakter dan kemampuan berikut dibutuhkan bagi para pimpinan.

Pimpinan nasional haruslah mempunyai kemampuan untuk melihat persoalan bangsa ini secara lebih menyeluruh dan mendalam. Dengan melihat persoalan yang pokok, diharapkan mereka dapat menentukan kebijakan yang tepat untuk mengatasi persoalan tersebut. Dengan demikian pimpinan tidak jatuh dalam keputusan dan kebijakan yang kecil-kecil dan tidak perlu, tetapi malah melupakan kebijakan dan keputusan penting bagi penanganan krisis bangsa ini.

Pimpinan nasional diharapkan mempunyai keberanian untuk melawan korupsi terlebih di tingkat pimpinan negara dan lembaga negara. Meski mafia korups sangat besar, pimpinan nasional diharapkan memberi contoh untuk bersih dari korupsi, lebih transparan dengan kekayaan pribadi dan keluarga. Mereka diharapkan dapat menggerakkan para pembantunya dan pimpinan lembaga-lembaga negara untuk 
berani memberantas korupsi. Yang biasanya sangat sulit adalah memberantas korupsi di tengah teman-teman dan keluarganya sendiri. Disini pimpinan diharapkan tegas bertindak meskipun tindakan tersebut menyangkut relasi, keluarga, teman yang terbukti melakukan tindak korupsi, bukan sebaliknya malah melindungi mereka.

Pimpinan nasional diharapkan menjadi orang yang netral di tengah konflik warga masyarakat. Mereka diharapkan menjadi penengah dengan menegakkan persatuan dan persaudaraan. Dalam hal ini hukum perlu ditegakkan sehingga tidak terjadi konflik terus menerus antara warga masyarakat. Pimpinan diharapkan mengembangkan pribadi yang suka damai, suka dialog dengan semua warga. Mereka diharapkan tidak menjadi otoriter, lebih demokratis, dan tidak suka memaksakan kehendak kepada masyarakat. Pimpinan diharapkan sungguh menghargai hak asasi manusia, tidak diskriminatif dalam keputusan dan tindakannya.

Pimpinan diharapkan dekat dengan rakyat, perhatian terhadap nasib rakyat kecil yang miskin. Selain memikirkan nasib orang besar, pimpinan perlu lebih perhatian kepada mereka yang tertindas, yang miskin, yang tidak mendapatkan tempat di masyarakat. Keadilan sosial harus menjadi perhatian pimpinan. Perhatian ini harus terwujud dalam kebijakan, undang-undang, dan peraturan yang dihasilkan pemerintah.

Pimpinan diharapkan mengembangkan akhlak dan moral yang tinggi berdasarkan nilai agama dan kemanusiaan. Sikap jujur, adil, memperhatikan kepentingan bangsa daripada kepentingan sendiri, tidak menyalahgunakan kekuasaan, menghargai nilai manusia, perlu dikembangkan dalam hidup dan tugas mereka.
Pimpinan harus sadar bahwa masalah bangsa ini sangat kompleks dan membutuhkan kerjasama dengan siapapun yang berkehendak baik. Maka pimpinan diharapkan mampu bekerjasama dan mempersatukan kekuatan bangsa ini untuk mengatasi persoalan nasional yang ada. Dalam konteks ini, pimpinan harus terbuka untuk mengangkat orang-orang yang sungguh ahii dan profesional dalam bidangnya guna memimpin lembagalembaga negara dan menangani persoalan yang terkait, bukannya hanya mendudukkan orang-orang separtai yang tidak punya kemampuan profesional dalam bidang yang ditangani. Inilah salah satu kendala kemajuan bangsa ini, yaitu hanya memilih orang dari kelompoknya sendiri, meski mereka tidak ahlj dan profesional dalam bidangnya. Zaman yang kompeks seperti sekarang membutuhkan ahli-ahli yang sungguh profesional untuk dapat memikirkan dan memecahkan persoalan yang dihadapi. Itulah sebabnya kolusi dan koneksi perlu diberantas.

\section{Peran Agama terhadap Kepemimpinan Nasional}

Setiap agama mengajarkan agar umatnya melaksanakan tugas dan tanggungjawab serta memperhatikan nilainilai moral agama yang dianut. Bila orang itu menjadi pimpinan, agama mengajarkan agar orang itu menjalankan tugas kepemimpinannya secara baik. Itulah yang diucapkan dalam janji dan sumpah para pimpinan negara, ingin melakukan tugas dan jabatan itu secara bertanggungjawab. Maka, tidak ada agama yang mengajarkan pengikutnya untuk korupsi, menyalahgunakan jabatannya untuk diri sendiri. Tidak ada agama yang mengajarkan pengikutnya agar bertindak tidak jujur, otoriter, melecehkan orang lain. Setiap agama 
mengajarkan yang sebaliknya yaitu kebaikan.

Persoalan muncul, mengapa banyak pimpinan yang beragama melakukan yang justru oleh agamanya dilarang atau diharamkan? Mengapa banyak pimpinan melakukan korupsi, meski agamanya melarang; melakukan penindasan pada orang atau kelompok lain, meksi agamanya melarang; bertindak tidak jujur, meski agama melarang?

Bila ternyata pimpinan yang beragama, bertindak berlawanan dengan ajaran agama yang dianutnya seperti diatas, dapat disebutkan beberapa alasan. Pertama, pimpinan itu beragama secara KTP saja demi tuntutan formal jabatannya. Bagi mereka yang penting dalam KTP tertulis atau kelihatan oleh orang banyak bahwa mereka beragama. Apa isi dan tuntutan agamanya tidak diperdulikan, bahkan tidak dicoba untuk dimengerti. Dalam hal ini jelas bahwa agama hanya digunakan sebagai pemenuh kepentingan pribadi, bukan untuk dihayati secara sungguh-sungguh. Kedua, orang itu tidak paham tentang ajaran agamanya karena belum atau tidak mendalami secara sungguh. Barangkali orang ini masih pemula yang belum paham. Bila memang alasannya seperti ini, maka orang itu dapat dibantu sehingga dia sungguh menghayati ajaran agamanya dan tidak bertindak yang berlawanan. Disini pimpinan agama punya peran untuk membantu. Ketiga, pimpinan itu memang sudah rusak suara hatinya. Meski mereka tahu bahwa yang dibuatnya itu salah dan melawan hukum agama dan hukum negara, tetapi tetap nekad melanggar. Apalagi mereka tahu bahwa mereka dapat mencari pembenaran lewat orang-orang ahli yang dibayarnya. Atau pimpinan itu memang merasa sudah ada diatas agama, sehingga dapat berbuat apapun menurut kemauannya sendiri.
Mereka menjadi otoriter dan malah akan menguasai atau menindas agama sendiri. Mereka inginnya menjadi penguasa dalam segala hal tidak mau taat pada nilai agama. Inilah yang terjadi dengan banyak pimpinan otoriter, diktator, yang meski beragama tetapi justru menghancurkan agama dan orang-orang lain yang taat beragama. Gila kekuasaan telah menggelapkan suara hati mereka. Keempat, pimpinan itu sedang mengalami godaan setan. Godaan bagi pimpinan yang dominan adalah menjadi gila kuasa, gila harta, gila seks, gila hormat. Karena keinginannya untuk mencari kekuasaan, harta duniawi, pemuasan nafsu seks, dan kehormatan yang sangat tinggi, sehingga lupa akan Tuhan sendiri yang menciptakan semua itu. Dalam situasi kegilaan tersebut, pimpinan dapat bertindak amoral, menindas rakyat, bahkan melakukan pembunuhan masal demi kekuasaanya tidak tergoyahkan. Bila pimpinan sedang dalam godaan kejahatan seperti itu, mereka masih dapat diingatkan. Disini sekali lagi peran agamawan dan pimpinan agama untuk menyadarkan, sehingga pimpinan itu bertobat dan merubah tingkah lakunya agar tidak menghancurkan masyarakat dan bangsa.

Karakter dan sifat pimpinan nasional yang dibutuhkan untuk dapat menghadapi krisis seperti diungkapkan diatas, jelas sangat didukung oleh ajaran agama bila pimpinan itu sendiri mengerti ajaran agamanya dan menghayati ajarannya. Maka dalam konteks peran agama terhadap kepemimpinan yang baik, terutama terletak pada bantuan ajaran agama yang dianut pimpinan untuk semakin rela dan berani melakukan tugasnya secara baik dan bertanggungjawab. Itu berarti bahwa pimpinan diharapkan bukan hanya secara formal beragama, tetapi sungguh melakukan ajaran agama mereka. Dengan melakukan 
sungguh-sungguh agamanya, pimpinan akan terpacu dan terdorong untuk melakukan fungsi dan jabatannya secara bertanggungjawab. Dan dalam hal jabatan yang menuntut pengorbanan atau pelayanan tinggi, pimpinan itu akan dikuatkan dari keyakinan agamanya yang dalam tersebut. Jadi agama yang dihayati secara mendalam dapat menguatkan seseorang untuk berani melawan korupsi meski menghadapi tantangan besar; orang berani jujur mengakui kesalahannya karena dorongan nilai agamanya yang sungguh dalam di batin mereka.

\section{Peran Masyarakat Agama dan Agamawan terhadap Pimpinan}

Masyarakat agama, terlebih para agamawan, juga dapat mempunyai peran yang kuat dalam penegakan kepemimpinan yang baik. Kadang terjadi pimpinan menyalah gunakan agama untuk kepentingan sendiri. Banyak pimpinan yang menjadi otoriter dengan dalih bahwa kehendaknya adalah dari Tuhan, kemudian memaksakan kehendaknya kepada masyarakat. Jelas hal ini tidak benar. Sebagai orang yang beragama, tindakan ini jelas sangat memalukan, karena menyalahgunakan nama Tuhan bagi kepentingannya sendiri. Dalam situasi seperti ini masyarakat agama dan terutama agamawan diharuskan bersikap kritis dan berani menegur.

Pimpinan yang otoriter dengan mengatasnamakan agama biasanya sangat jahat. Kebanyakan orang tidak berani menolak yang dikatakan sebagai perintah Tuhan, padahal itu perintah pimpinan yang jahat. Akibatnya masyarakat hanya menurut saja meski dalam hat mereka memberontak Dalam sifuasi seperti ini para agamawan diharapkan kritis, sehingga tidak terjadi penyelewenangan atas nama agama. Para agamawan diharapkan beran! menyadarkan masyarakat untuk lebih kritis terhadap para pimpinan negara mereka yang sewenang-wenang, terlebih yang mengatas namakan agama.

Sayangnya berdasar pengalaman. banyak juga tokoh agama dan agamawan yang tidak punya keberanian menyuarakan kritik mereka. Banyak agamawan yang karena telah menerima banyak fasjititas darı pimpinan negara, lebih bersikap diam meski melihat ketidakberesan dalam diri pimpinan negara. Dalam banyak pengalaman memang para pimpinan negara sering mendekati para pemuka agama untuk membantu mereka dengan memberikan banyak fasilitas. Disinilah model "suap" digunakan untuk membungkam suara kritis dari agamawan.

Apakah mungkin para agamawan menjadi semacam pembisik untuk menegakkan nilai moral dalam negara ini terhadap pimpinan nasional? Inilah juga persoalan yang perlu direnungkan oleh para agamawan terhadap kelangsungan negeri ini.

\section{Pimpinan dari Agama Mayoritas}

Waktu saya ditanya, apakah lebih senang bila pimpinan nasional dari agama saya atau agama orang lain.Dengan spontan menjawab, lebih baik pimpinan nasional berasal dari agama mayoritas. Teman saya kaget mengapa demikian, bukankah bila dari pemimpin seagama akan mendapatkan prioritas dan perhatian.

Meski dalam sistem demokrasi, siapapun dapat menjadi pimpinan nasional asal di pilih oleh rakyat. Tetapi untuk situasi Indonesia, lebih banyak keuntungan bila pimpinan nasional berasal dari agama yang mayoritas, yaitu Islam Mengapa demikian? 
Karena jika pimpinan ñasional dari agama Islam, maka akan lebih mudah diterima oleh kelompok mayoritas. Penolakan dan pertentangan yang dihadapi lebih kecil sehingga suasana negara lebih stabil. ,

Oleh karena pimpinan dari agama mayoritas, bila kebijakan, keputusan, dan tindakannya tidak sesuaj atau menyalahi ajaran agama atau hukum negara, maka masyarakat mayoritas akan mudah mengingatkan dengan tekanan-tekanan yang lebih keras. Itulah yang pernah terjadi di Filipina, karena pimpinannya Katolik dan mayoritas masyarakat Katolik, pada saat pimpinan korupsi dan otoriter, seluruh masyarakat mendesaknya, tanpa harus ada isu agama karena yang didesak dan mendesak berasal dari agama yang sama.

Oleh karena pimpinan dari agama mayoritas, bila suatu hari mereka memberikan prioritas pelayanan atau perhatian pada masyarakat yang seagama, hal ini tidak menjadi hambatan bagi yang minoritas. Bila pimpinan membantu yang mayoritas untuk maju, itu berarti kebanyakan bangsa ini maju juga. Sedangkan bila yang diprioritaskan minoritas, berarti hanya sebagian kecil dari bangsa ini yang dimajukan. Bila pimpinan memberikan prioritas kepada yang mayoritas, dan juga memberikan perhatian kepada yang minoritas. Hal tersebut tidak menjadi masalah bagi yang mayoritas karena mereka toh sudah diutamakan.Bila pimpinan yang berasal dari agama minoritas; memprioritaskan minoritas akan mendapat tentangan dari mayoritas; sedangkan bila dia tidak memberikan prioritas kepada yang minoritas, yang kenyataanya adalah kelompoknya, dia tidak akan mendapat dukungan dari kelompoknya sendiri.

\section{Indonesia Multi Agama dan Budaya}

Kenyataannya bangsa:Indonesia terdiri dari berbagai agama, budaya, level sosial, dan suku. Dengan kata lain situasi bangsa ini memang bineka, banyak perbedaan. Yang berbeda itu hanya akan kuat bila mereka memang mau hidup bersama dalam perbedaan, dan bukan menyeragamkan. Maka perlu dicari konsensus yang secara umum diterima, sedangkan secara detail dapat berbeda.

Dalam sejarah berdirinya negara ini, oleh para pendiri bangsa, meski mayoritasnya Islam, disepakati bahwa negara ini adalah negara Indonesia yang bukan negara agama. Itu berarti bahwa para pendiri bangsa sungguh ingin bangsa ini bersatu dan semua golongan dapat bekerjasama membangun bangsa yang kuat. Menurut kami, para pendiri bangsa ini sungguh hebat, mereka tidak memikirkan kelompoknya sendiri, tetapi keseluruhan sebagai bangsa. Semangat seperti itulah yang diharapkan dapat berkembang di hari-hari mendatang. Dan yang lebih hebat lagi adalah bahwa dari kelompok partai dan agama terkuat, justru dengan rela mendukung adanya negara kesatuan dengan menghargai kebinekaan itu.

Sesudah pemilu 2004 , perbedaan yang bermacam-macam ini perlu dimengerti oleh pimpinan nasional. Meski pimpinan berasal dari agama mayoritas; mereka harus menjadi pimpinan dari semua suku, agama dan masyarakat multibudaya Indonesia. Dengan kata lain mereka diharapkan sungguh memperhatikan semua warga, siapapun mereka. Maka sikap non diskriminatif, sikap memperhatikan kelompok lain menjadi sangat penting. Dan karena dia dari agama mayoritas, yang didukung banyak orang, maka dia 
seharusnya dapat memberikan penerimaan dan keamanan bahkan perlindungan bagi kelompok kecil.

Bila bangsa ini ingin kuat, maka memang yang saling berbeda itu harus mau menjalin kerjasama, mau hidup berdampingan, mau saling meneguhkan. Maka pimpinan mendatang sungguh ditantang, sejauh mana mereka mampu untuk menyatukan dan membangun kerjasama antar seluruh fenomen bangsa yang berbedabeda. Pimpinan diharapkan mampu menjadi fasilitator agar setiap kelompok warga rela bekerjasama secara sinergis mengembangkan negara ini. Pimpinan diharapkan mampu untuk menyadarkan semangat kebangsaan dan persaudaraan di tengah perbedaan yang ada.

$\because$ Padà jaman orde baru, untuk menyatukan perbedaan itu, pemerintah melakukan penyamarataan, penyeragaman di segala segi termasuk dalam hal agama. Akibatnya, kebebasan kelompok dan individu dilarang dan dimatikan. Cara itu jelas tidak tepat dan malah menghasilkan ketegangan dan mematikan kreativitas serta memiskinkan agama dan budaya. Di jaman demokrasi ini, kerjasama sinergis justru harus menghargai perbedaan dan membiarkan kreativitas dan perbedaan muncul. Disinilah pimpinan perlu belajar dan mencari cara yang tepat, yang sungguh memajukan kebersamaan tetapi sekaligus kemandirian pribadi dan kelompok.

Salah satu hal untuk menegakkan sinergis dan kerjasama adalah menegakkan hukum yang berlaku di negeri ini. Dengan hukum itu maka konflik yang berdasarkan perasaan dapat dikurangi dan lebih ditata dengan hukum yang berlaku. Tentu yang harus diperhatikan adalah bahwa hukum itu sendiri harus adil.
Yang menarik perhatian dengan pemitu saat ini adalah adanya banyak partai yang berdasarkan nilai agama tertentu. Gejala ini bagi kami menunjukkan beberapa hal. Pertama, masyarakat merasakan bahwa nilai agama dapat memberikan sumbangan positif dalam menangani situasi negara yang krisis. Kedua, masyarakat menginginkan agar nilai agama menjadi salah satu pedoman dalam hidup bermasyarakat yang sering tidak beres ini. Ketiga, masyarakat melihat bahwa krisis negara ini salah satunya disebabkan karena nilai agama tidak dihayati sungguh-sungguh oleh para pengelola negara. Oleh karena itu, pimpinan nasional diharapkan juga membantu pengembangan agama dari para warga. Pimpinan nasional diharapkan dapat memberikan kebebasaan agama-agama itu maju dan menjalankan nilai mereka secara mendalam. Yang perlu diperhatikan adalah agar perkembangan agama-agama para. warga itu tetap memperhatikan persatuan dan kerukunan antar agama yaing ada. Disinilah tantangan bagi pimpinan nasional yang tidak mudah. 'Disatu pihak harus memberikan kebebasan' beragama dan memajukan setiap agama, dilain pihak tetap menjaga persatuan dan kerjasama antar warga yang berbeda-beda agama tersebut.

Salah satu kendala besar pimpinan dari agama tertentu, adalah bila pemimpin tersebut menjadi fanatik dan diskriminatif terhadap yang lain. Bila pemimpin tersebut sangat fanatik dengan agamanya sendiri dan memaksakan yang lain sepertinya, maka akan runyam. Demikian juga bila karena terlalu menekankan agama sendiri, lalu dia menjadi diskriminatif terhadap agama yang lain, maka akibatnya kepemimpinannya tidak akan diterima oleh kelompok yang lain. Bila ini terjadi maka pemimpin tersebut akan kehilangan penerimaan. 
Tantangan pimpinan sesudah pemilu sangat besar, terutama dari nilai agama. Pimpinan diharapkan menjalankan nilai agamanya secara dalam, jujur, luas, dan mendalam. Diharapkan mereka mengembangkan nilai keterbúkaan, toleransi, dan penerimaan pada kelompok dan agama lain. Pimpinan juga diharapkan mengembangkan setiap agama dan membangun kerjasama serta kesatuan diantara mereka.

\section{Apakah Agamawan tepat Menjadi Pimpinan Nasional}

Kadang orang bertanya, apakah akan lebih baik bila pimpinan kita sekaligus seorang agamawan? Apakah seorang yang sekaligus menjadi pimpinan agama dan negara akan lebih bertugas secara baik karena keagamaan mereka lebih tinggi dan dalam? Apakah mungkin kedua segi itu dipersatukan dalam diri seseorang? Secara ideal, memang mungkin bahwa seseorang menjadi pimpinan negara dan agama sekaligus. Itulah yang terjadi dengan pimpinan suku di kelompok tradisional, mereka sekaligus pimpinan wilayah dan agama.

Untuk zaman sekarang ini, teriebih di Indonesia, nampaknya penggabungan kedua peran dan jabatan itu sangat sulit. Prasarat yang harus dipenuhi sangat berat, yaitu orang itu harıs sungguh seimbang dan mampu dalam kedua fungsi tersebut. Tampaknya, karena kedua tugas itu begitu berat, menjadikannya satu akan sangat berat, sehingga malah salah satu dikorbankan atau keduanya tidak dilakukan dengan baik. Sebagai seorang negarawan harus serius memperhatikan semua warganya dengan berbagai kebinekaannya, sedangkan sebagai pimpinan agama tertentu harus lebih memperhatikan kebutuhan kelompok agamanya. Dengan demikian dia akan kurang perhatian pada kelompok yang lain. Kadang isi hukum negara berbeda dengan hukum dari agamanya, maka sebagai pimpinan keduanya, dia akan mengalami kebingungan. Manakah yang diprioritaskan. dan ditaati?

Penggabungan kedua peran sebagai pimpinan negara dan agama dalam banyak pengalaman sejarah, sering menimbulkan persoalan, yaitu otoritarian. Karena dia sekaligus pimpinan negara dan agama, maka dapat terjadi dia menggunakan "kuasa" agama untuk menguatkan kekuasaan pemerintahannya. Bila hal ini terjadi, pimpinan dapat menjadi otoriter karena banyak keputusannya, termasuk yang tidak baik, dikuatkan dengan seakanakan itu "kehendak Tuhan." Dapat terjadi bila dia dikritik oleh masyarakat karena tingkah lakunya sebagai pimpinan negara, lalu merasa dikritik sebagai pimpinan agama, dan kemudian menjadi berang. Kebebasan mengekspresikan nilai agama sering dihambat karena kepentingan kekuasaan. Dalam banyak kasus, nilai yang diperjuangkan dalam pemerintahan dan agama berbeda. Misalnya, sebagai pimpinan negara cenderung mencari kekuasaan, sedang sebagai pimpinan agama justru harus rendah hati karena yang dipentingkan Tuhan. Maka, ada konflik di dalamnya. Dalam pengalaman sejarah, waktu Paus juga menjadi pimpinan negara, ternyata tidak dapat tahan lama. Karena akhirnya yang lebih dominan adalah sebagai pimpinan wilayah yang ingin melestarikan kekuasaan. Maka sekarang ini Paus hanya merupakan pimpinan agama'dan bukan negara lagi.

Agama dan politik memang tidak dapat dilepaskan, saling terkait. Keduanya dapat saling mengkritisi agar menjadi baik. Agama dapat menjadi nilai kritis bagi politik yang 
tidak benar. Sedangkan politik dapat mengkritisi agama yang kadang mandul karena hanya berkutat pada ibadah dan tidak mengubah hidup manusia lebih baik. Itulah yang dikritik oleh Karl Marx dengan agama sebagai candu masyarakat. Dalam benak Marx, agama hanya mengajari orang untuk menerima, untuk pasrah, dan tidak menyemangati untuk berjuang dengan gigih. Tentu Marx disini tidak melihat secara mendalam bagaimana keyakinan banyak orang akan agamanya telah menggerakkan mereka untuk berani mati menentang rezim yang otoriter dan berjuang sampai mati.

\section{Penutup}

Untuk negara Indonesia, yang kenyataannya adalah negara demokrasi, sangat jelas bahwa pimpinan diharapkan menjadi pimpinan yang bermoral tinggi. Menghadapi krisis bangsa yang banyak mengalami tantangan, pimpinan pasca pemilu 2004 dituntut sungguh-sungguh berani melawan korupsi, membangun kesatuan bangsa, menghargai hak asasi manusia dalam kepemimpinannya, memperhatikan kesejahteraan warga masyarakat yang miskin, dan memperhatikan pendidikan generasi muda. Pimpinan dituntut untuk lebih menomorsatukan kepentingan bangsa daripada kepentingannya sendiri dan kelompoknya. Untuk itu semua, jelas diharapkan pimpinan sendiri menghayati agamanya secara baik, mendalam, dan bertanggungjawab. Dalam penghayatan nilai agamanya, sebagai pimpinan seluruh bangsa yang terdiri dari berbagai kelompok, perlu pimpinan mengembangkan toleransi, keterbukaan, dan kerelaan untuk menerima kritik dari masyarakat.
Pimpinan negara disatu sisi diharapkan memberikan kebebasan, tempat, fasilitas bagi perkembangan setiap agama di Indonesia, terutama agar nilai-nilai agama itu sungguh dihayati oleh masyarakat pemeluknya; dan disisi lain harus membantu agar kerjasama dan persatuan antara warga yang berbeda agama itu dapat terwujud dengan baik.

Agar pimpinan negara yang beragama itu dapat terus melaksanakan tugas dan pelayanannya bagi negara secara bertanggungjawab dan dalam rel yang benar, peran agamawan dan masyarakat sangat besar. Mereka diharapkan selalu berani memberikan kritik dan saran agar pimpinan negara selalu refleksi. Para agamawan dan masyarakat ilmiah tidak boleh tinggal diam bila terjadi penyelewenangan dari pimpinan negara. Mereka harus berani menyuarakan suara masyarakat termasuk menyuarakan kritik moral dari nilai agama mereka:

\section{Daftar Puștaka}

Dister, Nico Syukur, 1982, Pengalaman dan Motivasi Beragama, Jakarta: Leppenas.

Hendropuspito,D. 1983, Sosiologi Agama, Yogyakarta: Kanisius.

Magnis Suseno, Franz, 1986, Kuasa dan Moral, Jakarta: Gramedia.

Suparno, Paul, 1998. Roh Baik dan roh Jahat, Yogyakarta:Kanisius.

Weij, Van der,P.A.2000, Filsuf-Filsuf Besar tentang. Manusia, Yogyakarta: Kanisius. 